\title{
Biocompatibility and biomineralization assessment of bioceramic-, epoxy-, and calcium hydroxide-based sealers
}

\section{Carlos Roberto Emerenciano BUENO \\ Diego VALENTIM \\ Vanessa Abreu Sanches MARQUES \\ João Eduardo GOMES-FILHO Luciano Tavares Angelo CINTRA Rogério Castilho JACINTO \\ Eloi DEZAN-JUNIOR}

Univ. Estadual Paulista- UNESP, Department of Endodontics, Araçatuba Dental School, Araçatuba, SP, Brazil.

Declaration of Interests: The authors certify that they have no commercial or associative interest that represents a conflict of interest in connection with the manuscript.

Corresponding Author:

Eloi Dezan Junior

E-mail:dezan@foa.unesp.br

DOI: 10.1590/1807-3107BOR-2016.vol30.0081

Submitted: Nov 09,2015

Accepted for publication: Mar 06, 2016

Last revision: Apr 25, 2016

\begin{abstract}
Obturation of the root canal system aims to fill empty spaces, promoting hermetic sealing and preventing bacterial activity in periapical tissues. This should provide optimal conditions for repair, stimulating the process of biomineralization. An endodontic sealer should be biocompatible once it is in direct contact with periapical tissues. The aim of this study was to evaluate the rat subcutaneous tissue response to implanted polyethylene tubes filled with Smartpaste Bio, Acroseal, and Sealapex and investigate mineralization ability of these endodontic sealers. Forty Wistar rats were assigned to the three sealers groups and control group, ( $\mathrm{n}=10$ animals/group) and received subcutaneous implants containing the test sealers, and the control group were implanted with empty tubes. After days 7, 15, 30, and 60, animals were euthanized and polyethylene tubes were removed with the surrounding tissues. Inflammatory infiltrate and thickness of the fibrous capsule were histologically evaluated. Mineralization was analyzed by Von Kossa staining and polarized light. Data were tabulated and analyzed via Kruskal-Wallis and Dunn's test. All tested materials induced a moderate inflammatory reaction in the initial periods. Smartpaste Bio induced the mildest inflammatory reactions after day 15 . No difference was observed among groups after days 30 or 60 . Von Kossa-positive staining and birefringent structures observed under polarized light revealed a larger mineralization area in Sealapex-treated animals followed by Smartpaste Bio-treated animals. At the end of the experiment, all tested sealers were found to be biocompatible. All sealers induced biomineralization, except Acroseal, which induced a mild tissue reaction.
\end{abstract}

Keywords: Inflammation; Calcium Hydroxide; Endodontics.

\section{Introduction}

Efficient cleaning and shaping of the root canal system is essential to achieve the biological and mechanical objectives of endodontic treatment. This involves removal of the pulp tissue and remains as well as microorganisms and their by-products while providing the appropriate conical shape for subsequent root canal filling to achieve the desired three-dimensional obturation. ${ }^{1}$ Gutta-percha alone as a filling material is not sufficient to provide adequate root canal system sealing. Adequate sealing requires the use of an endodontic sealer to fill gaps between the cone and root canal walls; this can be achieved by evenly applying the fluid sealer., ${ }^{2,3}$ As the 
sealer reaches the apical foramen, it comes in direct contact with the periapical tissue, and therefore should be biocompatible. Although the contact area is small, there is always concern regarding the adverse reactions that the sealer may cause on the tissues. ${ }^{4}$

Endodontic sealers are divided into different groups, according to their main components, such as zinc oxide and eugenol, resin, and calcium hydroxide. ${ }^{5}$ Depending on these main components, local adverse effects may occur, which delay or hinder repair. ${ }^{6}$

Bioceramic sealers are being introduced into the market. Their composition includes tricalcium and dicalcium silicates, calcium phosphates, calcium hydroxide, and zirconium oxide as a radiopacifier. All abovementioned components are applicable for biomedical and dental use and possess hydrophilic properties. ${ }^{78}$ The Smart Seal obturation system consists of a bioceramic sealer (Smartpaste Bio ${ }^{\circledR}$, CRD Ltd, Stamford, UK) identified as a hydroxyapatite-based cone polymer with an external layer of the expandable hydrophilic hydrogel Smartpoint. ${ }^{5,9}$ The manufacturer affirms that Smartpaste Bio produces hydroxyapatite and calcium hydroxide as by-products of a setting reaction consistent with alkaline $\mathrm{pH}$, antibacterial activity, radiopacity, and biocompatibility. ${ }^{10}$

Acroseal (Acroseal ${ }^{\circledR}$ Specialites-Septodont, Saint Maur-des-Fosses, France) is an endodontic sealer containing $28 \%$ calcium hydroxide, along with a radiopaque excipient and resin compound (epoxy resin). Previous studies have demonstrated antimicrobial activity against Enterococcus faecalis, low toxicity, and suitable physicochemical properties. ${ }^{11,12}$ According to the manufacturer, the sealer formulation has recently been modified with a reduction in the calcium hydroxide concentration and an increase in its resinous compound diglycidyl ether of bisphenol A (DGEBA).

Sealapex (Sealapex ${ }^{\circledR}$ SybronEndo, Glendora, CA) is a sealer that contains calcium oxide and forms calcium hydroxide after being hydrated on contact with the tissue fluid. Sealapex is characterized by biocompatibility and an osteoinductive ability to stimulate the deposition of mineralized tissue, thus inducing apical sealing after endodontic treatment. ${ }^{13,14}$ This sealer was submitted to a reformulation, which has a 2-year shelf life rather than the 1-year shelf life of the previous formulation. One of the major alterations in Sealapex is the change in the radiopacifier from barium sulfate to bismuth trioxide..$^{15}$

Only limited data concerning the Smart Seal obturation system are currently available, and there is a current lack of scientific studies regarding biocompatibility of Smartpaste Bio and its mineralization ability. Additionally, the components in the reformulated versions of Acroseal and Sealaplex need to be studied further.

The purpose of the present study was to analyze biocompatibility (inflammation response) of Smartpaste Bio, Acroseal, and Sealapex and investigate the mineralization ability of these endodontic sealers. The null hypothesis was that biocompatibility and mineralization were not induced by Smartpaste Bio, Acroseal, or Sealapex.

\section{Methodology}

Forty male 4-6-month-old Wistar rats, weighing 250-280 g, were used in the study. The animals were housed in temperature-controlled rooms and were provided with water and food ad libitum. Animal care was performed according to the Faculdade de Odontologia de Araçatuba, UNESP, Ethical Committee, which approved the experimental project.

One hundred and twenty polyethylene tubes (Abbott Laboratories of Brazil, Sao Paulo, SP, Brazil) with a $1.0 \mathrm{~mm}$ internal diameter, $1.6 \mathrm{~mm}$ external diameter, and $10.0 \mathrm{~mm}$ length were filled with the tested sealers. Acroseal and Sealapex were prepared according to the manufacturer's recommendations and inserted into the tubes with a lentulo spiral (Dentsply Maillefer, Tulsa, USA). Smartpaste Bio is available in a ready-to-use syringe and was directly inserted into the polyethylene tubes. Forty extra polyethylene empty tubes were used as controls, totaling to 160 tubes in the experiment.

After administration of xylazine $(10 \mathrm{mg} / \mathrm{kg}$ Rhobifarma Indústria Farmacêutica Ltda, Hortolândia, Brazil) and ketamine $(25 \mathrm{mg} / \mathrm{kg}$ União Química Farmacêutica Nacional S/A, São Paulo, Brazil) intramuscular anesthesia, the backs of the animals were shaved, antisepsis was obtained with $5 \%$ iodine solution, and a $2.0 \mathrm{~cm}$ incision was formed in a head-tail orientation with \#15 Bard-Parker blade (BD, Franklin Lakes, USA), creating two pockets on 
each side of the incision. Three polyethylene tubes, containing the sealers, and an empty tube, as the control, were implanted in each animal in opposite directions (upper right, upper left, lower right, and lower left), and the skin was closed with a $4 / 0$ silk suture (Johnson \& Johnson Produtos Profissionais Ltda, São José dos Campos, Brazil).

On days 7, 15, 30, and 60 after implantation, the animals were euthanized by an anesthetic overdose. Polyethylene tubes, with the surrounding tissues, were removed and fixed in $10 \%$ buffered formalin at $\mathrm{pH} 7.0 .^{16}$ The specimens were processed for glycol methacrylate embedding, ${ }^{17}$ serially cut into $3 \mu \mathrm{m}$ sections, and stained with hematoxylin-eosin (HE). The $10 \mu \mathrm{m}$ sections were stained according to the Von Kossa technique or were not stained.

Polarized light (PL) was used to observe birefrigent structures and the Von Kossa (VK) technique was used to observe biomineralization, as it darkly stains mineralized structures. ${ }^{18,19}$
Tissue reactions at the open end of the tubes were scored according to previous studies ${ }^{14,19,20}$ as follows: 0 , few inflammatory cells or no reaction; 1 , less than 25 cells and mild reaction; 2 , between 25 and 125 inflammatory cells and moderate reaction; and 3, 125 or more inflammatory cells and severe reaction $(400 \times$ magnification). Fibrous capsules were considered thin when $<150 \mu \mathrm{m}$ and thick when $>150 \mu \mathrm{m}$. Calcification was recorded as positive or negative by Von Kossa staining and present or absent under PL (100 × magnification).

Data were statistically analyzed by Kruskal-Wallis and Dunn's test; $p<0.05$ was considered significant.

\section{Results \\ Control group}

A moderate chronic inflammatory reaction (median score 2) was observed at the first two time periods (Table 1), i.e., on days 7 and 15 (Figures $1 \mathrm{~A}$ and B). Inflammatory cell infiltration, comprising lymphocytes and macrophages, was present in the fibrous capsule,

Table 1. Percentage of samples in each group categorized according to the inflammatory score and the rating thickness of fibrous capsule.

\begin{tabular}{|c|c|c|c|c|c|}
\hline \multirow{2}{*}{ Variable } & \multicolumn{4}{|c|}{ Score (\%) } & \multirow{2}{*}{ Capsule } \\
\hline & 0 & 1 & 2 & 3 & \\
\hline \multicolumn{6}{|l|}{7 Days } \\
\hline Control & 0 & 0 & 100 & 0 & Thick \\
\hline Sealapex & 0 & 0 & 90 & 10 & Thick \\
\hline Acroseal & 0 & 0 & 90 & 10 & Thick \\
\hline Smartpaste Bio & 0 & 0 & 100 & 0 & Thick \\
\hline \multicolumn{6}{|l|}{15 days } \\
\hline Control & 0 & 0 & 100 & 0 & Thick \\
\hline Sealapex & 0 & 0 & 90 & 10 & Thick \\
\hline Acroseal & 0 & 0 & 100 & 0 & Thick \\
\hline Smartpaste Bio & 0 & $80^{*}$ & 20 & 0 & Thin \\
\hline \multicolumn{6}{|l|}{30 days } \\
\hline Control & 0 & 100 & 0 & 0 & Thin \\
\hline Sealapex & 0 & 90 & 10 & 0 & Thin \\
\hline Acroseal & 0 & 90 & 10 & 0 & Thin \\
\hline Smartpaste Bio & 10 & 90 & 0 & 0 & Thin \\
\hline \multicolumn{6}{|l|}{60 Days } \\
\hline Control & 0 & 100 & 0 & 0 & Thin \\
\hline Sealapex & 0 & 60 & 40 & 0 & Thin \\
\hline Acroseal & 10 & 80 & 10 & 0 & Thin \\
\hline Smartpaste Bio & 10 & 80 & 10 & 0 & Thin \\
\hline
\end{tabular}

*Statistical difference. 
which was thick. In the 30- and 60-day samples, the fibrous capsule surrounding the tube was thin, with few inflammatory cells (median score 1). The control group was negative for Von Kossa stain and no birefringent structures were observed under PL at all time periods (Table 2).

\section{Smartpaste Bio}

Only on day 7, a moderate inflammatory cell infiltration, comprising lymphocytes and macrophages, was present in the thick fibrous capsule. On days 15, 30 , and 60 , the intensity of the inflammation was reduced (median score 1) and the fibrous capsule was thin, similar to that observed in the control group (Figure 1). Granulations birefringent to PL were present mostly on day 7. From days 15 to 60 , the birefringent granulations started to disappear (Table 2). Von Kossa positive stains were observed at all time periods.

Table 2. Percentage of samples in each group categorized according to Von Kossa positive to mineralization and presence of birefrigents crystals under polarized light.

\begin{tabular}{|c|c|c|}
\hline Variable & Von Kossa (\%) & Polarized Light (\%) \\
\hline \multicolumn{3}{|l|}{7 days } \\
\hline Control & 0 & 0 \\
\hline Sealapex & 100 & 100 \\
\hline Acroseal & 0 & 0 \\
\hline Smartpaste Bio & 100 & 100 \\
\hline \multicolumn{3}{|l|}{15 days } \\
\hline Control & 0 & 0 \\
\hline Sealapex & 100 & 100 \\
\hline Acroseal & 0 & 0 \\
\hline Smartpaste Bio & 100 & 50 \\
\hline \multicolumn{3}{|l|}{30 days } \\
\hline Control & 0 & 0 \\
\hline Sealapex & 100 & 100 \\
\hline Acroseal & 0 & 0 \\
\hline Smartpaste Bio & 100 & 50 \\
\hline \multicolumn{3}{|l|}{60 Days } \\
\hline Control & 0 & 0 \\
\hline Sealapex & 100 & 100 \\
\hline Acroseal & 0 & 0 \\
\hline Smartpaste Bio & 100 & 30 \\
\hline
\end{tabular}

\section{Acroseal}

On days 7 and 15, a moderate inflammatory cell infiltration (median score 2), comprising lymphocytes and macrophages, was present in a thick fibrous capsule (Table 1 ). On days 30 and 60 , the inflammation intensity reduced and the fibrous capsule was thin, similar to that observed in the control group (Figure $1 \mathrm{~K}, \mathrm{~L}$ ). Birefringent granulations to PL were absent and Von Kossa was negative at all time periods (Figure $2 \mathrm{I}-\mathrm{P}$ )

\section{Sealapex}

On days 7 and 15, a moderate inflammatory reaction (median score 2), consisting mainly of lymphocytes and macrophages, was present in the thick fibrous capsule (Table 1). The intensity of the inflammation reduced from day 30 to day 60 , exhibiting the remaining macrophages phagocyting extravasated sealer (median score 1). The fibrous capsule near the tube opening was thin (Figure 1G,H) and granulations birefringent to PL and Von Kossa positive staining were observed near the tube opening at all time periods (Figure $2 \mathrm{~A}-\mathrm{H}$ ).

\section{Comparison among groups}

Data were compared for each time period as shown in Table 1 and 2. After day 7, HE staining revealed a tissue response similar to that of an inflammatory reaction, and there were no statistically significant differences among the inflammation scores of the experimental groups. On day 15 , there was a statistically significant difference between inflammatory cell numbers in the Smartpaste Bio and other groups; the inflammatory score was lower than that of the other groups $(\mathrm{p}<0.05)$ and it also presented a thin fibrous capsule. On days 30 and 60, there was no statistically significant difference among scores of the different groups, with respect to the inflammation tissue response.

PL and Von Kossa analysis revealed that Acroseal had no mineralization induction at any time periods, unlikeSealapex, which presented birefrigent structures under PL and Von Kossa positive staining at all time periods (Table 2). Smartpaste Bio samples presented birefrigent structures and Von Kossa positive staining 




Figure 1. Subcutaneous tissue reactions in the experimental groups. Control group: $(A, B)$ thick fibrous capsule and moderate inflammatory reaction (days 7 and $15, \mathrm{HE}, 100 \times$ ), (C) reduction in the thickness of the fibrous capsule and mild inflammatory reaction (day $30, \mathrm{HE}, 100 \times$ ), and $(\mathrm{D})$ thin fibrous capsule and mild inflammatory reaction (day 60, HE, $10 \times$ ). Sealapex: $(E, F)$ thick fibrous capsule formation and moderate inflammatory cell infiltration (days 7 and 15, HE, $100 \times$ ); $(G)$ reduction in the thickness of the fibrous capsule formation and mild inflammatory cell infiltration, consisting of macrophages $(\mathrm{day} 30, \mathrm{HE}, 100 \times)$; and $(\mathrm{H})$ thin fibrous capsule formation and mild inflammatory cell infiltration, with macrophages phagocyting sealer (day $60 \mathrm{HE}, 100 \times)$. Acroseal: $(I, J)$ thick fibrous capsule and moderate inflammatory cell infiltration (days 7 and $15, \mathrm{HE}, 100 \times)$ and $(K, L)$ the fibrous capsule surrounding the tube was thin with few chronic inflammatory cells (days 30 and 60, HE, 100×). Smarpaste Bio: (M) thick fibrous capsule and moderate inflammatory reaction (day $7 \mathrm{HE}, 100 \times$ ) and $(N-P)$ thin fibrous capsule and mild inflammatory reaction (days 15, 30, and 60, $\mathrm{HE}, 100 \times$ );

in $100 \%$ of the specimens until day 15 and decreased over time, differentiating from each time period along the experiment, but maintaining the already mineralized structures (Table 2).

\section{Discussion}

In our study, all tested sealers, except Acroseal, promoted mineralization, and all sealers demonstrated biocompatibility; therefore, we rejected the null 


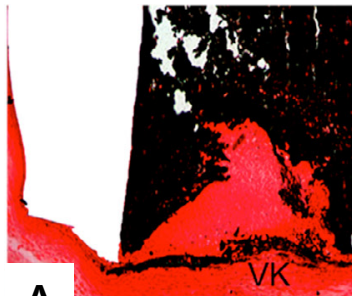

A
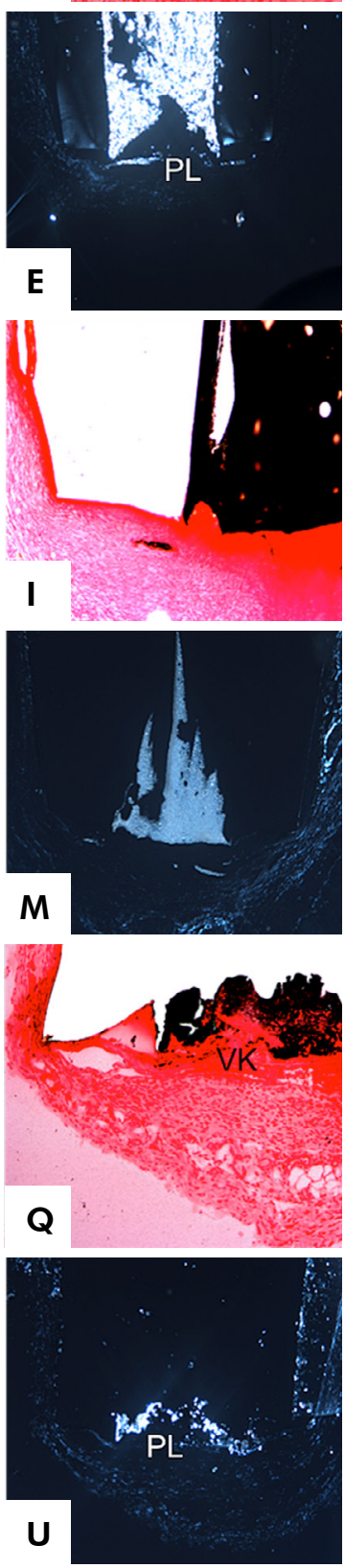
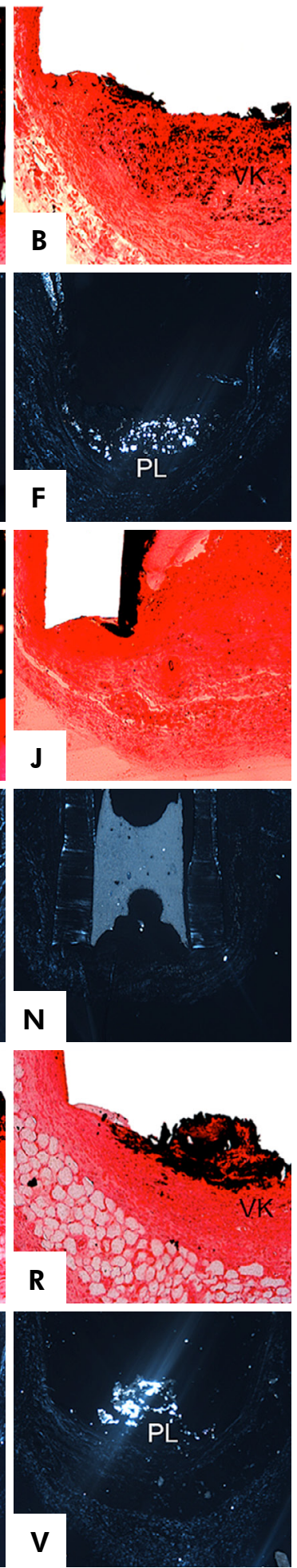
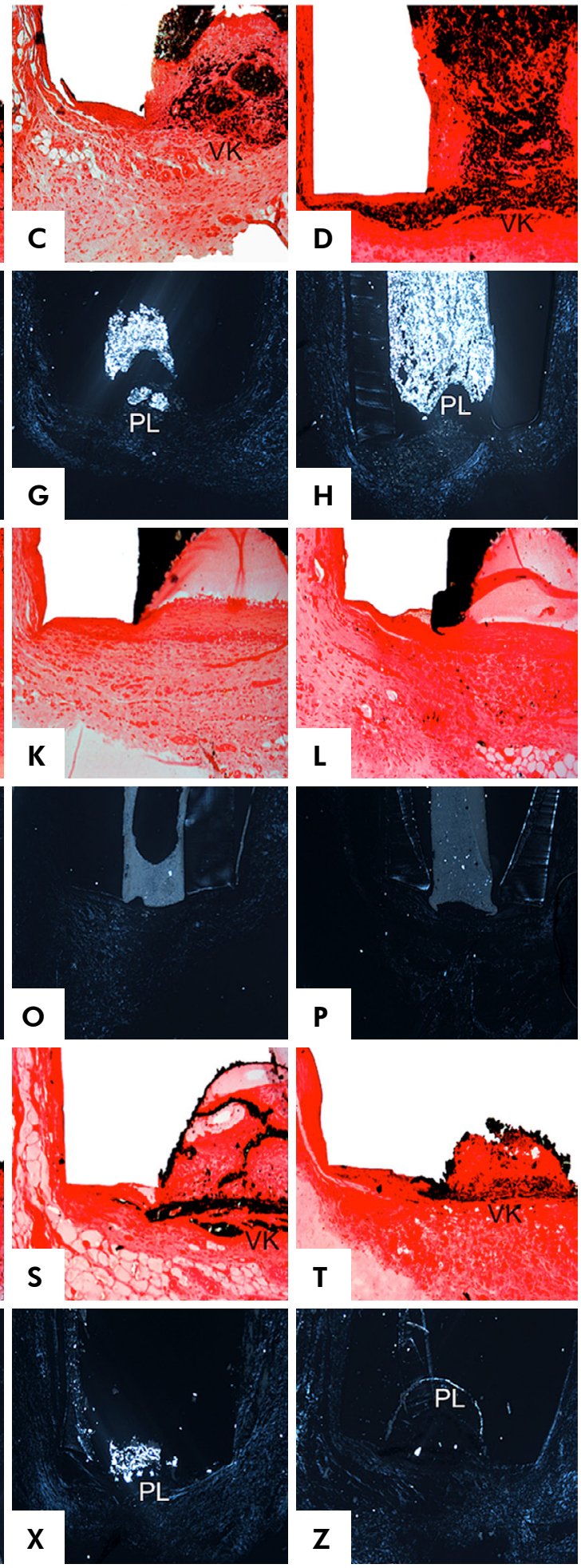

Figure 2. Biomineralization in the experimental groups. Sealapex: $(A-D)$ the presence of dystrophic calcification on the tube opening (days 7, 15, 30, and 60; Von Kossa, $10 \times$ ) and $(\mathrm{E}-\mathrm{H})$ the presence of birefringent structures under polarized light (days 7, 15, 30, and 60, polarized light $5 \times$ ); Acroseal: (I-L) the absence of dystrophic calcification on the tube opening (days $7,15,30$, and 60; Von Kossa, 10X) and (M-P) the absence of birefringent structures under polarized light (days 7, 15, 30, and 60; polarized light, $5 \times$ ); and Smartpaste Bio: $(Q-T)$ the presence of dystrophic calcification on the tube opening (days 7, 15, 30, and 60; Von Kossa, $10 \times)$ and $(U-Z)$ the presence of birefringent structures under polarized light, slightly disappearing through the time periods (days 7, 15, 30, and 60; polarized light, $5 \times$ ). 
hypothesis. The mild-to-moderate inflammatory reactions induced in all groups during the initial experimental periods subsequently decreased and the fibrous capsule became thinner.

The use of subcutaneous implants was initiated by Torneck. ${ }^{21}$ His pioneering research, which aimed to evaluate the reaction of the subcutaneous connective tissue of rats to implanted polyethylene tubes, became a commonly used preliminary method to evaluate biocompatibility. ${ }^{22,23}$ Here the reactions to empty tubes were similar to those that were previously reported. ${ }^{16,24}$

Previous studies reported that a glycol methacrylate technique was an excellent alternative for the evaluation of biocompatibility of endodontic sealers; this technique is easy to execute and reproducible and thereby provides a better definition of the degree of the inflammatory process. ${ }^{17}$ The specimens were cut into $3 \mu \mathrm{m}$ sections and stained with HE to analyze the inflammatory infiltrate. Scores used to analyze inflammatory reactions were consistent with those reported in previous studies. ${ }^{14,16,19}$ The $10 \mu \mathrm{m}$ sections were stained according to the Von Kossa technique to observe mineralized structures or unstained to allow observation of birefringent structures under PL which are related to calcium carbonate crystals. ${ }^{18,25}$

The reaction of calcium ions from $\mathrm{Ca}(\mathrm{OH})_{2}$ and the ionic dissociation of carbon dioxide from the tissues results in the formation of calcite crystals that are birefringent to PL, and induce the formation of calcified areas. Moreover, the use of calcium reduces the presence of carbon dioxide, which is used by bacteria for anaerobic respiration, ${ }^{26}$ whereas the high $\mathrm{pH}$ provided by the hydroxyl favors the tissue restoration process and antimicrobial properties. ${ }^{27,28}$

Endodontic sealers containing calcium oxide have been suggested as obturating materials because of their capacity to dissociate into calcium and hydroxyl ions, resulting in a higher $\mathrm{pH}$ that favors repair and induces mineralized tissue formation. ${ }^{13,26,35,39}$

The setting time could favor a calcium ion release that generally occurs before the setting of materials. ${ }^{36}$ Although Acroseal has a long setting time, ${ }^{12}$ its calcium release was inferior to that with Sealapex because of the relative insolubility of its epoxy base. This finding illustrates the need for calcium hydroxide-based sealers to be minimally soluble and liberate hydroxyl and calcium ions, ${ }^{35}$ which explains the absence of mineralization observed in this study.

With respect to Smartpaste Bio, the use of a pre-mixed sealer eliminates the potential of heterogeneous consistency during on-site mixing. Studies involving other bioceramic endodontic sealers already revealed hard tissue deposition ${ }^{29}$ and favorable tissue response to partial pulpotomy. ${ }^{30}$ Monobasic calcium phosphates are included in the sealer to facilitate the reaction with calcium hydroxide to produce water and hydroxyapatite upon activation of the sealer by water. ${ }^{31}$

Previous studies on bioceramic sealers have revealed lower inflammatory mediators and better osteoblast expression, thus indicating that the bioceramic is biocompatible. ${ }^{32,33}$ These earlier findings on the biocompatibility of bioceramic sealers also match the results of this study.

Bioceramics are sealers that are recently used in endodontic treatment, with a restricted literature concerning its physical and chemical properties. These calcium silicate sealers have been claimed to be excellent in endodontic obturation with an alkaline $\mathrm{pH}$ and solubility. An in vitro study conducted in 2015 revealed that the solubility of Smartpaste Bio promotes alkalinity and calcium release superior to that with a MTA-based sealer after setting time. ${ }^{40}$

Birefrigent granulations were present in all tissues $(100 \%)$ at initial time periods, and they decreased over time in the Smartpaste Bio group. This is probably related to a reduction in calcium release after day 30 , but the mineralized structures stained by Von Kossa were positive for all time periods.

Even with the reformulation, Acroseal maintained biocompatibility, inducing a low inflammatory response and no mineralized areas were observed in any time period, similar to previous results. ${ }^{34}$

In a calcium release study, Sealapex presented high calcium and hydroxyl release, particularly after longer time intervals, which were verified in this in vivo study by the presence of birefrigent granulations under PL from day 7 to day 60, and biomineralization at all time periods. ${ }^{36}$ 
Previous studies with the original formulation of Sealapex presented mild inflammation during initial periods, which reduced over time. ${ }^{37}$ Analyzing the new formulation of Sealapex, inflammatory infiltrate increased at day $14 .^{38}$ and at day 90 of the experimental period, ${ }^{15}$ suggesting that the alterations might have affected tissue compatibility. The results in this research reveal a moderate initial inflammatory response, decreasing after day 30 .

\section{References}

1. Schilder H. Filing root canals in three dimensions. J Endod. 20061;32(4):281-90. doi:10.1016/j.joen.2006.02.007

2. Weis MV, Parashos P, Messer HH. Effect of obturation technique on sealer cement thickness and dentinal tubule penetration. Int Endod J. 2004;37(10):653-63. doi:10.1111/j.1365-2591.2004.00839.x

3. Rahimi M, Jainaen A, Parashos P, Messer HH. Bonding of resin-based sealers to root dentin. J Endod. 2009;35(1):121-4. doi:10.1016/j.joen.2008.10.009

4. Chhabra A, Teja TS, Jindal V, Singla MG, Warring K. Fate of extruded sealer: a matter of concern. J Oral Health Comm Dent. 2011;5(3):168-72.

5. Kim YK, Grandini S, Ames JM, Gu LS, Kim SK, Pashley DH et al. Critical review on methacrylate resin-based root canal sealers. J Endod. 2010;36(3):383-99. doi:10.1016/j.joen.2009.10.023

6. Geurtsen W. Biocompatibility of root canal filling materials. Aust Endod J. 2001;27(1):12-21. doi:10.1111/j.1747-4477.2001.tb00445.x

7. Koch K, Brave D. Bioceramic technology: the game changer in endodontics. Endodontic Practice US. 2009;12:7-11.

8. Zhang W, Li Z, Peng B. Assessment of a new root canal sealer's apical sealing ability. Oral Surg Oral Med Oral Pathol Oral Radiol Endod. 2009;107(6):e79-82. doi:10.1016/j.tripleo.2009.02.024

9. Economides N, Gogos C, Kodonas K, Beltes C, Kolokouris I. An ex vivo comparison of the push-out bond strength of a new endodontic filling system (Smartseal) and various gutta-percha filling techniques. Odontology. 2012;100(2):187-91. doi:10.1007/s10266-011-0040-3

10. Prosmart. Propoint: $21^{\text {st }}$ century obturation: product information. Stamford: Prosmart; 2009 [cited 2015 Sep 16]. Available from: http://www.smart-seal.co.uk/wp-content/ uploads/downloads/2011/04/Prosmart-technical-info.pdf

11. Pinheiro CR, Guinesi AS, Camargo EJ, Pizzolitto AC, and Bonetti-Filho I. Bacterial leakage evaluation of root canals filled with different endodontic sealers. Oral Surg Oral Med Oral Pathol Oral Radiol Endod. 2009;108(6):e56-60. doi:10.1016/j.tripleo.2009.08.008

\section{Conclusion}

At the end of the experiment, all tested sealers were biocompatible, with a statistical difference observed with Smartpaste Bio at day 15. All sealers induced biomineralization, except for Acroseal. Further studies are necessary to better analyze the behavior of this bioceramic material and its physicochemical properties and to confirm the findings of the present study.

12. Marciano MA, Guimarães BM, Ordinola-Zapata R, Bramante CM, Cavenago BC, Garcia RB et al. Physical properties and interfacial adaptation of three epoxy resin-based Sealers. J Endod. 2011;37(10):1417-21. doi:10.1016/j.joen.2011.06.023

13. Holland R, Souza V Ability of a new calcium hydroxide root canal filling material to induce hard tissue formation. J Endod. 1985;11(12):535-43. doi:10.1016/S0099-2399(85)80199-0

14. Gomes-Filho JE, Watanabe S, Lodi CS, Cintra LT, Nery MJ, Otobon Filho JA et al. Rat tissue reaction to MTA FILLAPEX. Dent Traumatol. 2012;28(6):452-6. doi:10.1111/j.1600-9657.2011.01096.x

15. Leonardo MR, Barnett F, Debelian GJ, Lima RKP, Silva LAB. Root canal adhesive filling in dogs' teeth with or without coronal restoration: a histopathological evaluation. J Endod. 2007;33(11):1299-303. doi:10.1016/j.joen.2007.07.037

16. Gomes-Filho JE, Watanabe S, Bernabé PFE, Costa MTM. A mineral trioxide aggregate sealer stimulated mineralization. J Endod. 2009;35(2):256-60. doi:10.1016/j.joen.2008.11.006

17. Gomes-Filho JE, Gomes BPFA, Zaia AA, Novaes PD, Souza-Filho FJ. Glycol methacrylate: an alternative method for embedding subcutaneous implants. J Endod .2001;27(4):266-8. doi:10.1097/00004770-200104000-00005

18. Holland R, Souza V, Nery MJ, Otoboni-Filho JA, Bernabé PFE, Dezan-Júnior E. Reaction of rat connective tissue to implanted dentin tubes filled with mineral trioxide aggregate or calcium hydroxide. J Endod. 1999;25(3):161-6. doi:10.1016/S0099-2399(99)80134-4

19. Cintra LTA, Ribeiro TAAR, Gomes-Filho JE, Bernabé PF, Watanabe S, Facundo AC et al. Biocompatibility and biomineralization assessment of a new root canal sealer and root-end filling material. Dent Traumatol. 2013;29(2):145-50. doi:10.1111/j.1600-9657.2012.01142.x

20. Yaltirik M, Ozbas H, Bilgic B, Issever $H$.

Reactions of connective tissue to mineral trioxide aggregate and amalgam J Endod. 2004;30(2):95-9. doi:10.1097/00004770-200402000-00008 
21. Torneck CD. Reaction of rat connective tissue to polyethylene tube implants part I. Oral Surg Oral Med Oral Pathol. 1966;21(3):379-87. doi:10.1016/0030-4220(66)90077-6

22. Zmener O, Guglielmotti MB, Cabrini RL. Tissue response to an experimental calcium hydroxide-based endodontic sealer: a quantitative study in subcutaneous connective tissue of the rat. Endod Dent Traumatol. 1990;6(2):66-72. doi:10.1111/j.1600-9657.1990.tb00393.x

23. Kaplan AE, Ormaechea MF, Picca M, Canzobre MC, Ubios AM. Rheological properties and biocompatibility of endodontic sealers. Int Endod J. 2003;36(8):527-32. doi:10.1046/j.1365-2591.2003.00683.x

24. Olsson B, Sliwkowski A, Langeland K. Subcutaneous implantation for the biological evaluation of endodontic materiald. J Endod. 1981;7(8):355-67. doi:10.1016/S0099-2399(81)80057-X

25. Gomes-Filho JE, de Faria MD, Bernabé PF, Nery MJ, Otoboni-Filho JA, Dezan-Júnior E et al. Mineral trioxide aggregate but not light-cure mineral trioxide aggregate stimulated mineralization. J Endod. 2008;34(1):62-5. doi:10.1016/j.joen.2007.09.018

26. Holland R, Souza V, Nery MJ, Bernabé F, Filho JA, Junior ED et al. Calcium salts deposition in rat connective tissue after implantation of calcium hydroxide-containing sealers. J Endod. 2002;28(3):173-6. doi:10.1097/00004770-200203000-00007

27. Tagger M, Tagger E, Kfir A. Release of calcium and hydroxyl ions from set endodontic sealers containing calcium hydroxide. J Endod. 1988;14(12):588-91. doi:10.1016/S0099-2399(88)80055-4

28. Desai S, Chandler N. Calcium hydroxide-based root canal sealers: a review. J Endod. 2009;35(4):475-80. doi:10.1016/j.joen.2008.11.026

29. Güven EP, Taşlı PN, Yalvac ME, Sofiev N, Kayahan $\mathrm{MB}$, Sahin F. In vitro comparison of induction capacity and biomineralization ability of mineral trioxide aggregate and a bioceramic root canal sealer. Int Endod J. 2013;46(12):1173-82. doi:10.1111/iej.12115

30. Azimi S, Fazlyab M, Sadri D, Saghiri MA, Khosravanifard B, Asgary S. Comparison of pulp response to mineral trioxide aggregate and a bioceramic paste in partial pulpotomy of sound human premolars: a randomized controlled trial. Int Endod J. 2014;47(9):873-81. doi:10.1111/iej.12231
31. Yang Q, Troczynski T, Liu DM. Influence of apatite seeds on the synthesis of calcium phosphate cement. Biomaterials. 2002;23(13):2751-60. doi:10.1016/S0142-9612(02)00010-8

32. Chang SW, Lee SY, Kang SK, Kum KY, Kim EC. In vitro biocompatibility, inflammatory response, and osteogenic potential of 4 root canal sealers: Sealapex, Sankin apatite root sealer, MTA Fillapex, and iRoot sp root canal sealer. J Endod. 2014;40(10):1642-8. doi:10.1016/j.joen.2014.04.006

33. Bósio CC, Felippe GS, Bortoluzzi EA, Felippe MCS, Felippe WT, Rivero ERC. Subcutaneous connective tissue reactions to iRoot SP, mineral trioxide aggregate (MTA) Fillapex, DiaRoot BioAggregate and MTA. Int Endod J. 2014;47(7):667-74. doi:10.1111/iej.12203

34. Gomes-Filho JE, Bernabé PFE, Nery MJ, Otoboni-Filho JA, Dezan-Júnior E, Costa MMM et al. Reaction of rat connective tissue to a new calcium hydroxide- based sealer. Oral Surg Oral Med Oral Pathol Oral Radiol Endod. 2008;106(2):e71-6. doi:10.1016/j.tripleo.2008.03.030

35. Eldeniz AU, Erdemir A, Kurtoglu F, Esener T. Evaluation of $\mathrm{pH}$ and calcium ion release of Acroseal sealer in comparison with Apexit and Sealapex sealers. Oral Surg Oral Med Oral Pathol Oral Radiol Endod. 2007;103(3):e86-91. doi:10.1016/j.tripleo.2006.10.018

36. Duarte MA, Demarchi AC, Giaxa MH, Kuga MC, Fraga $\mathrm{SC}$, de Souza LC. Evaluation of $\mathrm{pH}$ and calcium ion release of three root canal sealers. J Endod. 2000;26(7):389-90. doi:10.1097/00004770-200007000-00002

37. Mittal M, Chandra S, Chandra S. Comparative tissue toxicity evaluation of four endodontic sealers. J Endod. 1995;21(12):622-4. doi:10.1016/S0099-2399(06)81116-7

38. Silva-Herzog D, Ramírez T, Mora J, Pozos AJ, Silva LA, Silva RA et al. Preliminary study of the inflammatory response to subcutaneous implantation of three root canal sealers. Int Endod J. 2011;44(5):440-6. doi:10.1111/j.1365-2591.2011.01849.x

39. Duarte MA, Demarchi ACO, Yamashita JC, Kuga MC, Fraga SC. $\mathrm{pH}$ and calcium ion release of 2 root-end filling materials. Oral Surg Oral Med Oral Pathol Oral Radiol Endod. 2003;95(3):345-7. doi:10.1067/moe.2003.12

40. Abu Zeid STH, Mokeem Saleh AAY. Solubility, $\mathrm{pH}$ Changes and releasing elements of different bioceramic and mineral trioxide aggregate root canal sealers comparative study. J Trauma Treat. 2015;4:249. doi:10.5301/jabfm.5000230 